\title{
Perancangan Sistem Modulator Binary Phase Shift Keying
}

\author{
Deddy Susilo, Budihardja Murtianta ${ }^{2}$, Arivia Aurelia Devina Pramono ${ }^{3}$ \\ Program Studi Teknik Elektro, \\ Fakultas Teknik Elektronika dan Komputer, \\ Universitas Kristen Satya Wacana, Salatiga \\ 11deddy.susilo@staff.uksw.edu, ${ }^{2}$ budihardja.murtianta@staff.uksw.edu, \\ ${ }^{3}$ me_230104@yahoo.com
}

\begin{abstract}
Ringkasan
Sistem yang dibangun adalah sebuah modul sistem modulator BPSK (Binary Phase Shift Keying). Perangkat yang dibahas adalah modulator BPSK dengan frekuensi $10 \mathrm{kHz}-48 \mathrm{kHz}$ dan untuk transmisi secara nirkabel ditambahkan pemancar FM yang akan mentranslasikan sinyal pembawa pada frekuensi radio sebesar $80 \mathrm{MHz}$. Berdasarkan pengujian yang telah dilakukan, sistem perangkat modulator BPSK yang dibangun dapat bekerja dengan baik. Perancangan pseudorandom generator dengan menanamkan algoritma register geser 5 tingkat dengan mikrokontroler AVR ATTINY13A dapat diatur dengan bit rate bervariasi dari 1200, 2400, 4800 dan 9600 bps. Untai tapis lolos rendah Bessel orde 2 dengan fc $48 \mathrm{kHz}$ dapat berfungsi memperhalus hasil keluaran pseudorandom generator dan level shifter. Untai selektor keluaran BPSK dapat berfungsi dengan baik untuk pemilih sinyal sinus $0^{\circ}$ dan $180^{\circ}$ serta pemancar FM dapat menghasilkan spectrum sinyal paling tinggi pada frekuensi $80 \mathrm{MHz}$.
\end{abstract}

Kata kunci: modulator, pseudorandom generator, costas loop, suppressed carrier, mikrokontroler.

\section{Pendahuluan}

Pemilihan sistem modulasi pada suatu transmisi digital berdasarkan karakteristik yang dimiliki oleh sistem tersebut, yaitu lebar pita, daya yang disediakan dan ketahanan terhadap gangguan. Penulis mencoba meneliti modulasi digital BPSK (Binary Phase Shift Keying) dengan pertimbangan lebar pita transmisi yang efisien dan Quality of Service (QoS) yang dihasilkan sangat baik[1][2][3]. Modulasi PSK (Phase Shift Keying) adalah modulasi digital yang dilakukan dengan mengubah fasa dari sinyal referensi tertentu. Modulasi BPSK adalah modulasi PSK yang menggunakan 2 macam perubahan fasa, yaitu $0^{\circ}$ dan $180^{\circ}$. Untuk proses demodulasi BPSK harus dilakukan secara koheren[4]. Deteksi koheren adalah deteksi yang membutuhkan informasi fasa dan frekuensi asli dari sinyal pembawanya secara tepat[5]. Masalah pada deteksi koheren adalah bagaimana mendapatkan informasi tentang frekuensi dan fasa asli sinyal pembawa menggunakan sinyal pembawa yang telah termodulasi fasanya[6], proses ini sering disebut carrier recovery. Pada umumnya terdapat dua metode yang sering digunakan untuk carrier recovery pada deteksi koheren sinyal BPSK, yaitu Squaring Loop dan Costas Loop[2][5]. Seperti dijelaskan pada [1], sistem komunikasi menggunakan BPSK membutuhkan modulator dan demodulator. Pada tulisan sebelumnya [2] penulis telah 
mengimplementasikan perangkat keras demodulator BPSK dengan Costas Loop. Pada tulisan ini, penulis menyajikan perancangan dan implementasi perangkat keras modulator BPSK.

\section{Modulasi dan Demodulasi BPSK}

Seperti telah dijelaskan sebelumnya, modulasi BPSK menyatakan bit 1 dan 0 dengan menggunakan fasa yang berbeda. Biasanya digunakan beda fasa 180 derajat antara bit 1 dengan bit 0 . Sebuah modulator BPSK dapat direalisasikan dengan menggunakan sebuah modulator setimbang yang akan mengalikan data biner dengan format bipolar (NRZ Bipolar) dengan sinyal pembawanya, seperti dapat dilihat pada gambar 1 .

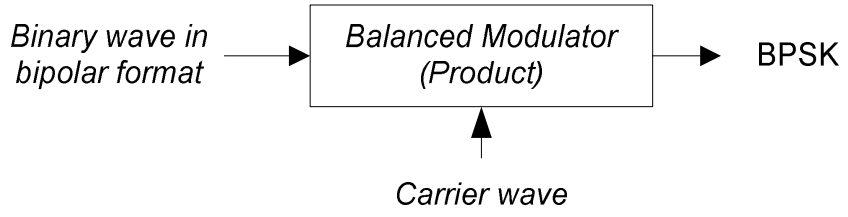

Gambar 1. Diagram Blok Modulator BPSK Sederhana.

Sinyal BPSK dapat dinyatakan dengan persamaan berikut

$$
s(t)=\left\{\begin{array}{cl}
A_{c} \cos \left(\omega_{c} t\right) & , \text { saat logika } 1 \\
A_{c} \cos \left(\omega_{c} t+\pi\right)=-A_{c} \cos \left(\omega_{c} t\right) & , \text { saat logika } 0
\end{array}\right.
$$

Jika dinyatakan dengan data biner format bipolar, maka Persamaan 1 dapat dinyatakan dengan Persamaan 2 berikut ini.

$$
s(t)=m(t) A_{c} \cos \left(\omega_{c} t\right)
$$

Dengan $m(t)$ adalah sinyal data biner dinyatakan dengan persamaan :

$$
m(t)= \begin{cases}+1 & , \text { saat logika } 1 \\ -1 & , \text { saat logika } 0\end{cases}
$$

Pada prakteknya, modulator BPSK sering direalisasikan dengan diagram blok dan proses pembentukan sinyal BPSK seperti yang ditunjukkan pada gambar 2 dan 3.

Keluaran dari sumber data digital biasanya masih berupa sinyal NRZ Unipolar. Sinyal NRZ Unipolar adalah sinyal digital yang menyatakan logika ' 1 ' dengan level tegangan tertentu (+A Volt) dan logika ' 0 ' dengan level tegangan 0 Volt. Sedangkan sinyal NRZ Bipolar menyatakan logika ' 1 ' dengan level tegangan positif tertentu (+A Volt) dan logika ' 0 ' dengan level tegangan negatif tertentu (-A Volt). Perbandingan sinyal NRZ Unipolar dengan sinyal NRZ Bipolar dapat dilhat pada gambar 4.

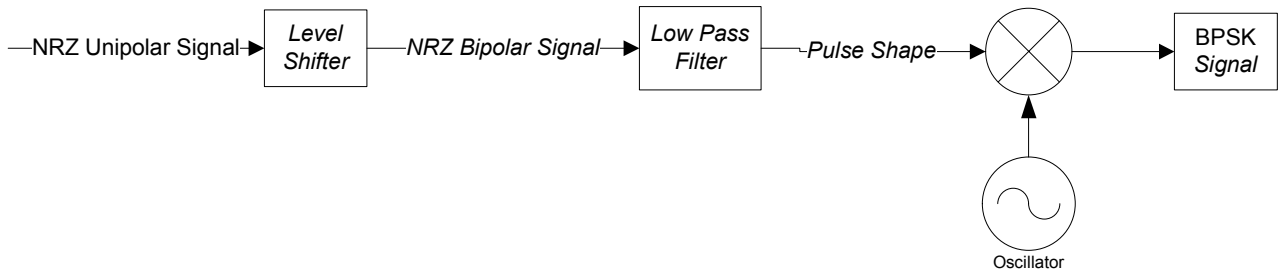

Gambar 2. Diagram Blok Modulator BPSK. 


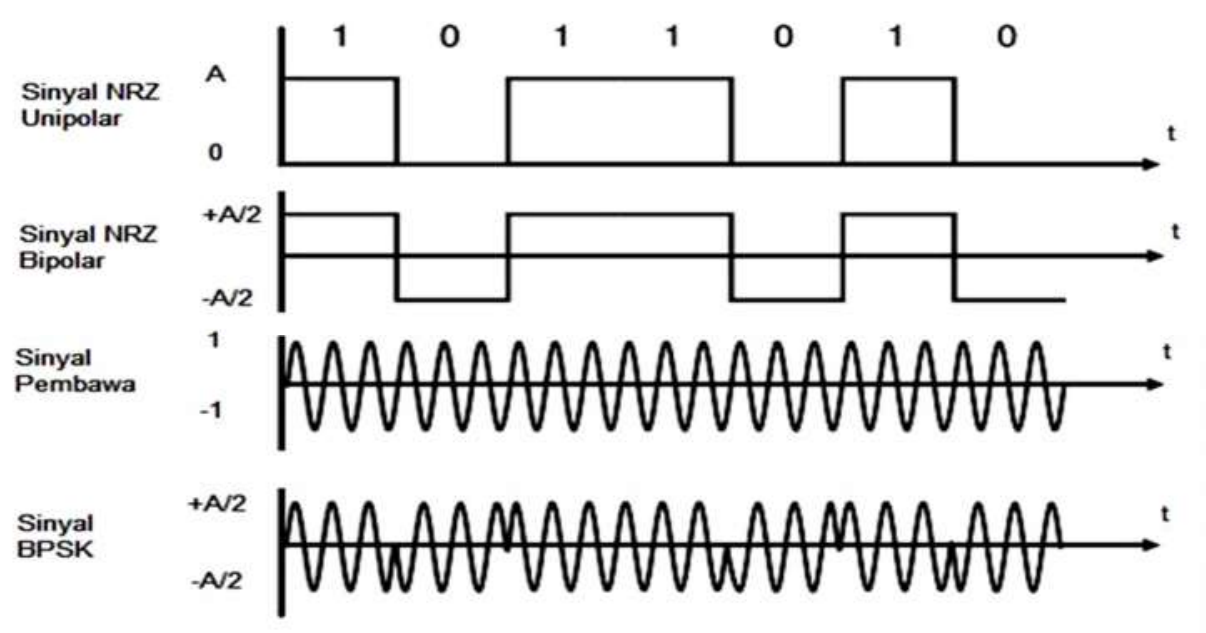

Gambar 3. Proses Pembentukan Sinyal BPSK.

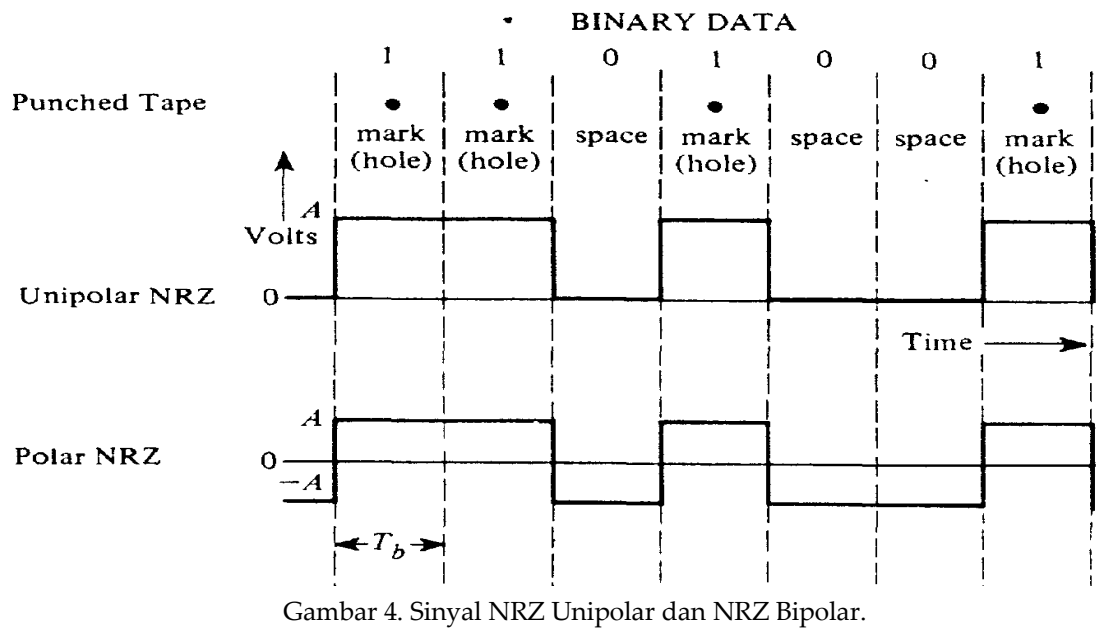

Pada proses modulasi sinyal BPSK, sinyal NRZ Unipolar akan diubah menjadi sinyal NRZ Bipolar oleh suatu untai Level Shifter. Keluaran dari Level Shifter akan dikalikan dengan sinyal pembawa yang dihasilkan oleh osilator, hasil perkalian ini akan menghasilkan sinyal BPSK. Pada perancangan suatu modulator BPSK sering ditambahkan tapis pelewat rendah (LPF), yang digunakan untuk membatasi lebar pita dari sinyal BPSK yang dihasilkan.

\section{Perancangan Pemancar BPSK}

Perancangan bagian pemancar meliputi perancangan 3 bagian utama, yaitu perancangan simulator data sebagai sumber data digital yang akan ditransmisikan, perancangan modulator BPSK dan perancangan modulator FM.

\subsection{Perancangan Simulator Data (Pseudo Random Generator)}

Simulator data adalah sumber sinyal informasi biner yang akan dimodulasikan dan dikirimkan. Simulator data yang akan digunakan adalah suatu Pseudo Random Generator (PRG). Diagram blok untai PRG ditunjukkan pada Gambar 5. 


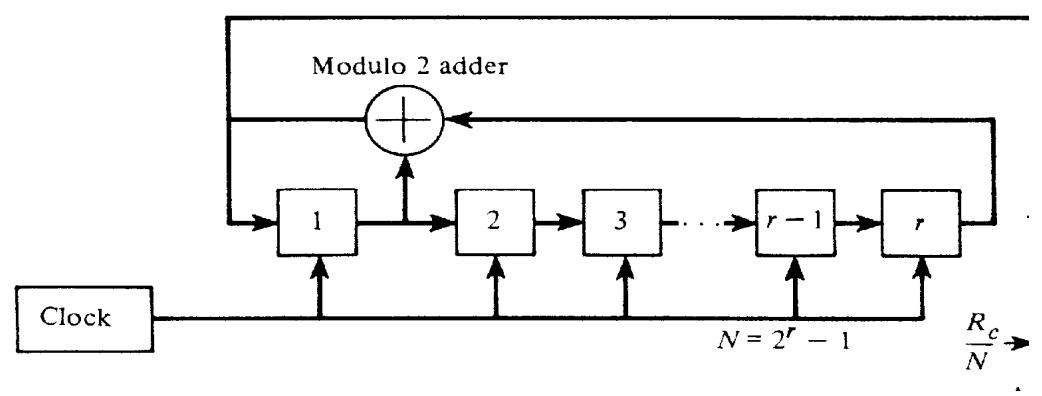

Gambar 5. Diagram Blok PRG

PRG pada gambar 5 akan menghasilkan deretan bit dengan pola acak yang periodik. Jumlah bit acak yang dihasilkan bergantung pada jumlah register geser yang digunakan. Karena menggunakan 5 buah register geser, maka akan dihasilkan $2^{5}-1=31$ bit acak. Untuk merealisasikan untai PRG digunakan rangkaian mikrokontroler AVR AT TINY 13A. Gambar 6(a) dan (b) menunjukkan pin-pin pada mikrokontroler AT TINY13A dan realisasi skematik dari PRG berbasis mikrokontroler. Untai PRG akan menghasilkan bit-bit biner pada level tegangan TTL (0 Volt untuk logika 0 dan 5 Volt untuk logika 1). Bit-bit biner seperti ini sering disebut sinyal unipolar NRZ.

\subsection{Perancangan Modulator BPSK}

Secara umum modulator BPSK terdiri dari 4 bagian utama, yaitu level shifter yang berguna untuk mengubah sinyal NRZ unipolar menjadi NRZ bipolar, tapis pelolos rendah (LPF) untuk menghilangkan derau, pencampur (mixer) dan osilator sinyal pembawa, yang tersusun seperti pada gambar 2 sebelumnya. Pada bagian selanjutnya akan dijabarkan perancangan tiap-tiap bagian modulator BPSK.

\subsubsection{Untai Level Shifter}

Bagian Level Shifter digunakan untuk mengubah sinyal informasi keluaran bagian simulator data yang merupakan sinyal NRZ Unipolar menjadi sinyal NRZ Bipolar untuk kemudian menjadi masukan rangkaian mixer. Sinyal bipolar inilah yang menyebabkan keluaran di mixer dapat memiliki beda fasa 0 atau 180 derajat.

Proses Level Shifter ini dapat dilakukan dengan mengurangkan sinyal data biner NRZ Unipolar dengan sinyal referensi tertentu.

$$
V_{\text {out }}(t)=2 V_{\text {ref }}-m(t)
$$

dimana :

$$
\begin{aligned}
& m(t)=\left\{\begin{array}{ll}
5 \mathrm{~V} & , \text {,untuk bit } 1 \\
0 V & , \text { untuk bit } 0
\end{array}\right. \text { adalah sinyal informasi NRZ Unipolar } \\
& V_{\text {ref }}=\text { tegangan referensi. }
\end{aligned}
$$

Jika dipilih $V_{r e f}=1,25 \mathrm{~V}$, maka akan didapatkan sinyal NRZ Bipolar dengan keluaran Level Shifter dapat dinyatakan sebagai berikut :

$$
V_{\text {out }}(t)=2 V_{\text {ref }}-m(t)= \begin{cases}-2,5 \mathrm{~V} & \text {, untuk bit } 1 \\ +2,5 \mathrm{~V} & \text {, untuk bit } 0\end{cases}
$$

Untuk merealisasikan untai Level Shifter digunakan untai penguat differential yang ditunjukkan seperti pada gambar 7 . 
Perancangan Sistem Modulator Binary Phase Shift Keying Deddy Susilo, Budihardja Murtianta, Arivia Aurelia Devina Pramono

(a)

Pinout of ATtiny $13 \mathrm{~A}$
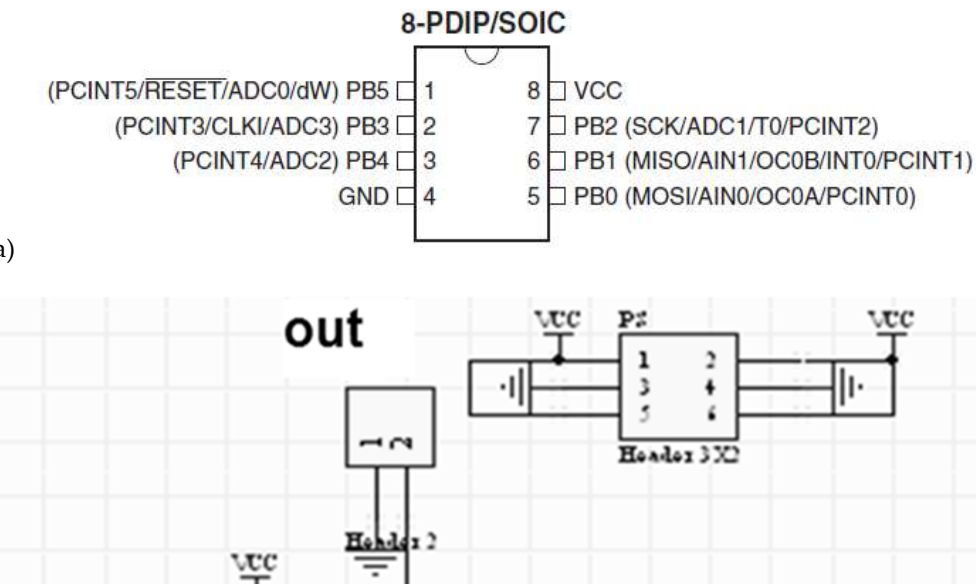

(b)

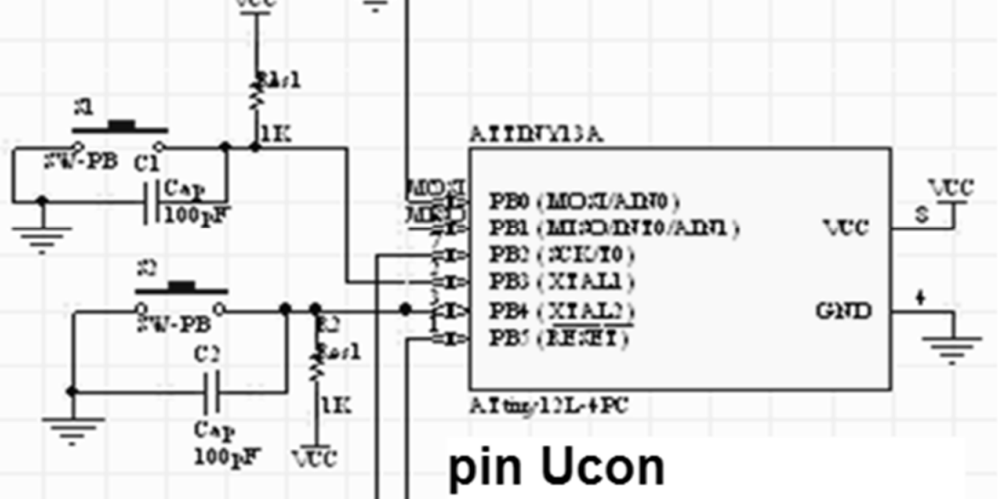

Gambar 6.(a). Pin-Pin AT TINY13A. (b). Skematik pembangkit PRG berbasis mikrokontroler.

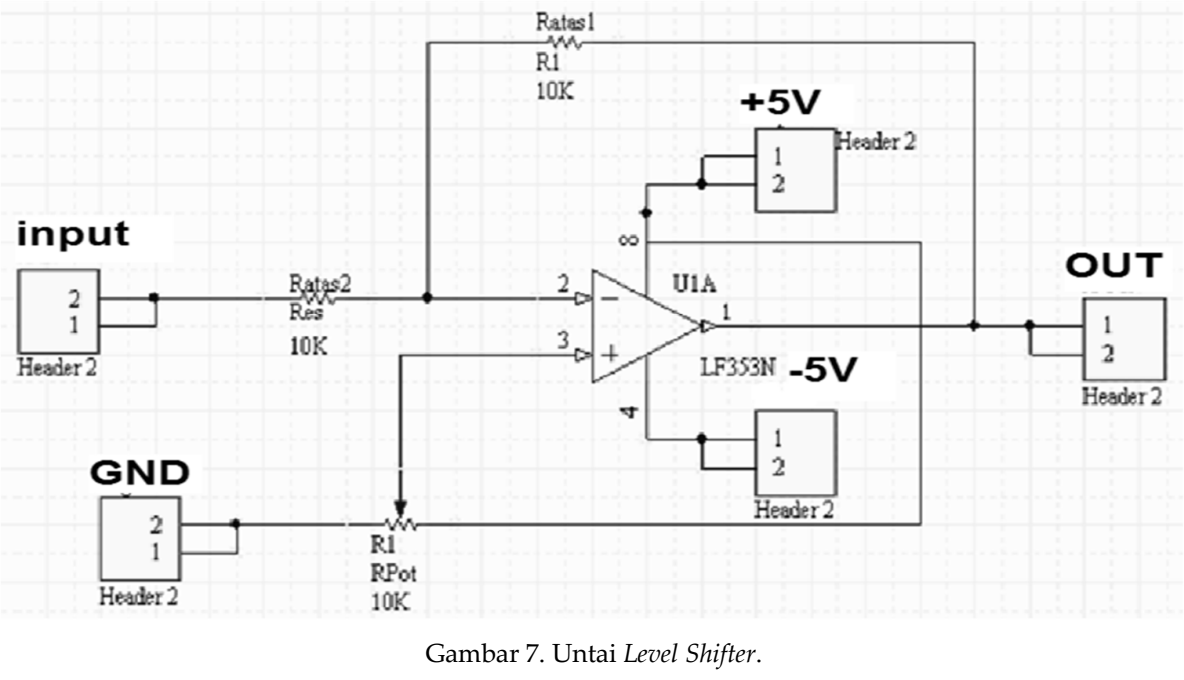




\subsubsection{Tapis Lolos Rendah}

Dalam perancangan ini akan ditambahkan sebuah tapis lolos rendah yang digunakan untuk mengurangi derau sebelum sinyal informasi masuk ke dalam pencampur. Pada perancangan ini dipilih tapis Bessel, karena tapis ini memiliki respon fasa yang linier untuk jangkauan frekuensi yang lebar dan filter ini juga memiliki group delay yang konstan pada jangkauan frekuensinya[8]. Perbandingan group delay antara tapis Bessel, Butterworth dan Tschebyscheff dapat dilihat pada gambar 8.

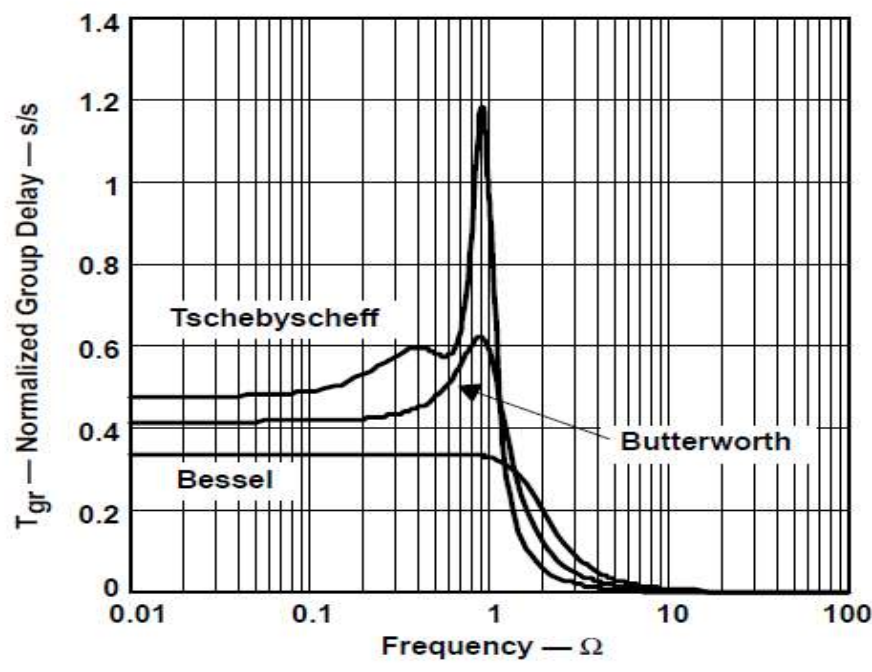

Gambar 8. Perbandingan group delay tapis-tapis klasik.

Sifat tapis Bessel yang memiliki group delay yang konstan inilah yang menyebabkan tapis Bessel memiliki kinerja optimum pada transmisi sinyal kotak. Hal ini disebabkan karena sinyal kotak memiliki banyak komponen frekuensi yang menyusunnya, dan dalam transmisi diharapkan setiap komponen frekuensi sinyal kotak memiliki tundaan yang sama, sehingga tidak menyebabkan distorsi pada sinyalnya.

Pada perancangan ini digunakan tapis Bessel orde 6. Tapis ini memiliki frekuensi penggal 96kHz. Untuk merealisasikan tapis orde 6 dilakukan dengan mengkaskade 3 buah tapis orde 2. Gambar 9 adalah skematik tapis lolos rendah orde 2 dengan menggunakan topologi Sallen-Key.

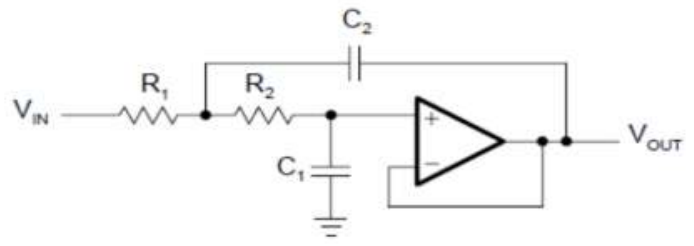

Gambar 9. Skematik tapis lolos rendah Sallen Key orde 2.

Tapis ini memiliki fungsi pindah seperti yang ditunjukkan dengan persamaan 6 .

$$
A(s)=\frac{1}{1+\omega_{c} C_{1}\left(R_{1}+R_{2}\right) s+\omega_{c}^{2} R_{1} R_{2} C_{1} C_{2} s^{2}}
$$

dengan $\omega_{c}$ adalah frekuensi penggal dari tapis lolos bawah dalam radian. 
Perancangan Sistem Modulator Binary Phase Shift Keying Deddy Susilo, Budihardja Murtianta, Arivia Aurelia Devina Pramono

Berdasarkan persamaan 6 akan didefinisikan koefisien-koefisien tapis yaitu $a_{i}$ dan $b_{i}$ yang dinyatakan dengan Persamaan 7 dan 8.

$$
\begin{gathered}
a_{i}=\omega_{c} C_{1}\left(R_{1}+R_{2}\right) \\
b_{i}=\omega_{c}^{2} R_{1} R_{2} C_{1} C_{2}
\end{gathered}
$$

Tapis Bessel orde 6 memiliki koefisien-koefisien sebagai berikut.

Tabel 1. Koefisien Tapis Bessel

\begin{tabular}{|c|c|c|}
\hline & $a_{i}$ & $b_{i}$ \\
\hline Tapis 1 & 1,2217 & 0,3887 \\
\hline Tapis 2 & 0,9686 & 0,3503 \\
\hline Tapis 3 & 0,5131 & 0,2756 \\
\hline
\end{tabular}

Dengan memasukkan frekuensi penggal tapis sebesar $\omega_{c}=2 \pi f_{c}=2 \pi \times 96000$ radian dan koefisien-koefisien tapis seperti yang tercantum di Tabel 1 ke dalam Persamaan 6, 7 dan 8, maka dapat dicari besarnya resistor dan kapasitor yang diperlukan untuk tiap-tiap tapis orde dua. Gambar 10 berikut ini adalah hasil realisasi tapis Bessel orde 6.

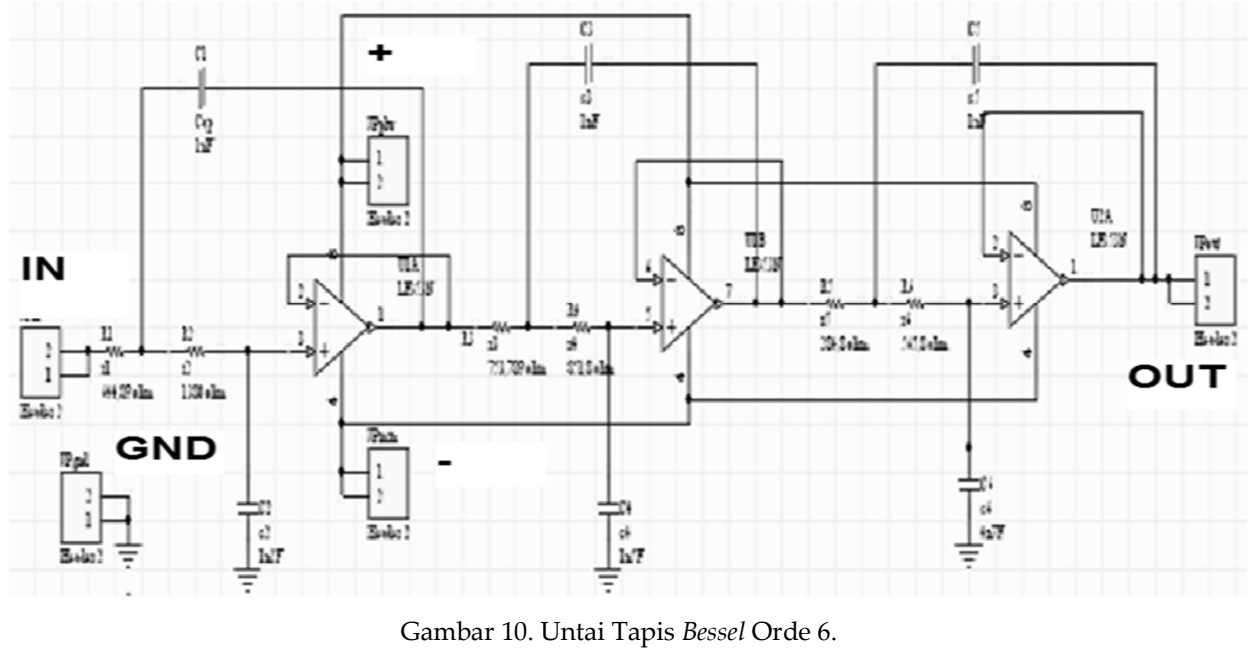

\subsubsection{Osilator}

Bagian osilator digunakan sebagai penghasil sinyal pembawa frekuensi tinggi yang digunakan untuk menumpangkan data. Osilator yang digunakan harus memiliki jangkauan frekuensi pembawa $10 \mathrm{kHz}-50 \mathrm{kHz}$ seperti yang tertera pada spefikasi. IC XR2206 yang digunakan dalam perancangan osilator. XR2206 adalah IC Monolithic Function Generator yang sering digunakan untuk pembangkit bentuk gelombang, pembangkit sinyal sweep, pembangkit sinyal $A M / F M$, pembangkit sinyal FSK dan Phase Locked Loops. Rangkaian Osilator dengan menggunakan IC XR2206 dapat dilihat pada gambar 11. Berdasarkan gambar 11, frekuensi sinyal keluaran diatur oleh nilai resistor pada pin 7 dan kapasitor diantara pin 5 dan 6. Frekuensi sinyal keluaran dinyatakan dengan persamaan 9. Agar dapat menjangkau frekuensi $10 \mathrm{kHz}-50 \mathrm{kHz}$, maka digunakan kapasitor sebesar $1 \mathrm{nF}$, dan resistor sebesar $16 \mathrm{Kohm}$ yang dihubung seri dengan potensiometer $200 \mathrm{Kohm}$.

$$
f=\frac{1}{R C}
$$




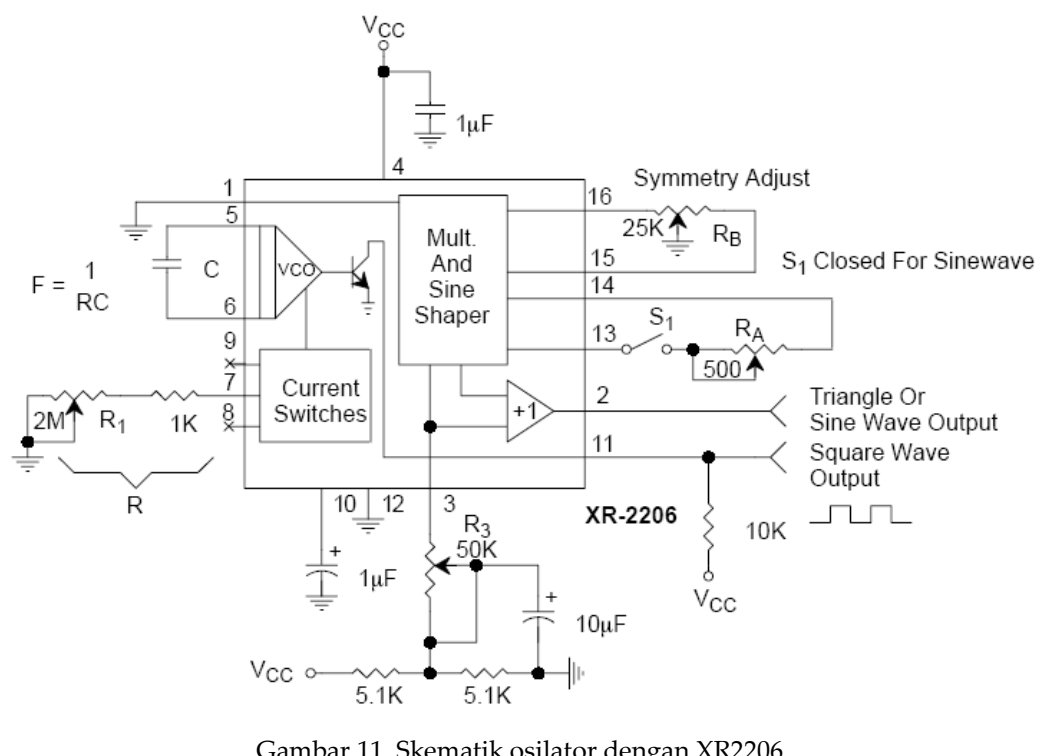

\subsubsection{Untai Selektor Keluaran BPSK}

Untuk mempermudah realisasi pencampur (mixer), di gunakan untai selektor. Bagian ini akan menghasilkan sinyal dengan beda fasa 0 dan 180 derajat untuk logika 1 dan 0 . Untuk merealisasikan untai selektor secara sederhana dapat dilakukan dengan menggunakan sebuah saklar analog yang tersusun seperti pada diagram blok pada Gambar 12.

Saklar analog berfungsi seperti multiplexer, yaitu dengan mengatur tegangan pada $V_{\text {control }}$, dapat diatur jalur 1 atau jalur 2 yang akan dikeluarkan ke keluaran $V_{\text {out }}$. Jika $V_{\text {control }}<0$, maka maka jalur 1 akan dikeluarkan ke $V_{\text {out }}$. Sedangkan jika $V_{\text {control }}>0$, maka jalur 2 akan dikeluarkan ke $V_{\text {out }}$. Dapat dilihat pada Gambar 13, masukan jalur 1 berasal dari keluaran osilator yang dilewatkan ke suatu penguat membalik. Jika keluaran dari osilator dinyatakan dengan persamaan $A_{c} \cos \left(\omega_{c} t\right)$, maka sinyal yang masuk ke jalur 1 adalah :

$$
V_{1}=-A_{c} \cos \left(\omega_{c} t\right)
$$

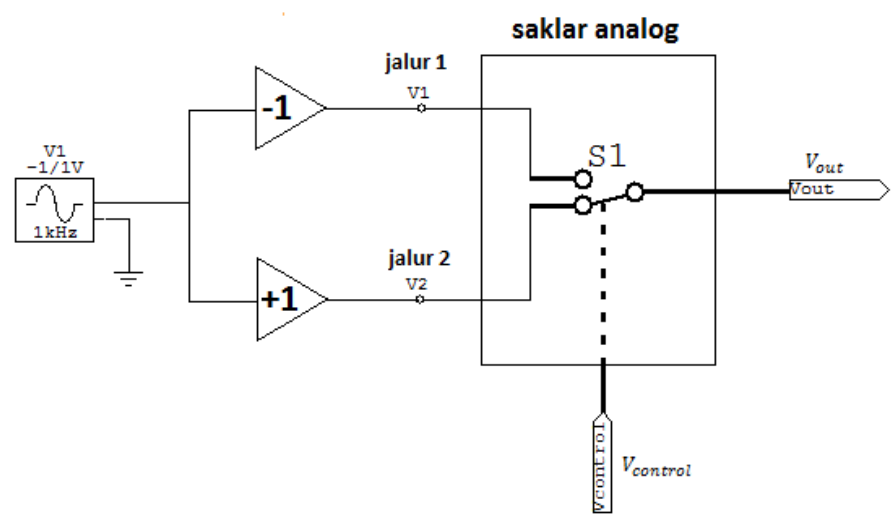

Gambar 12. Diagram Saklar Analog. 
Untuk jalur 2, sinyal masukan berasal dari keluaran osilator yang dilewatkan ke suatu penyangga (buffer), sehingga sinyal yang masuk ke jalur 2 dapat ditulis :

$$
V_{2}=+A_{c} \cos \left(\omega_{c} t\right)
$$

Dengan memberikan sinyal masukan sinyal NRZ bipolar yang berasal dari level shifter ke tegangan pengontrol $\left(V_{\text {control }}\right)$, maka dapat dihasilkan sinyal keluaran dengan fasa yang berubah-ubah antara 0 dan 180 derajat, yaitu sinyal $A_{c} \cos \left(\omega_{c} t\right)$ dan $-A_{c} \cos \left(\omega_{c} t\right)$ yang bergantung pada tegangan pengontrolnya. Dengan cara ini dapat dihasilkan sinyal BPSK. Untuk merealisasikan suatu saklar analog akan digunakan IC 4052 dan untuk merealisasikan penguat membalik dan penyangga digunakan IC Opamp 741.

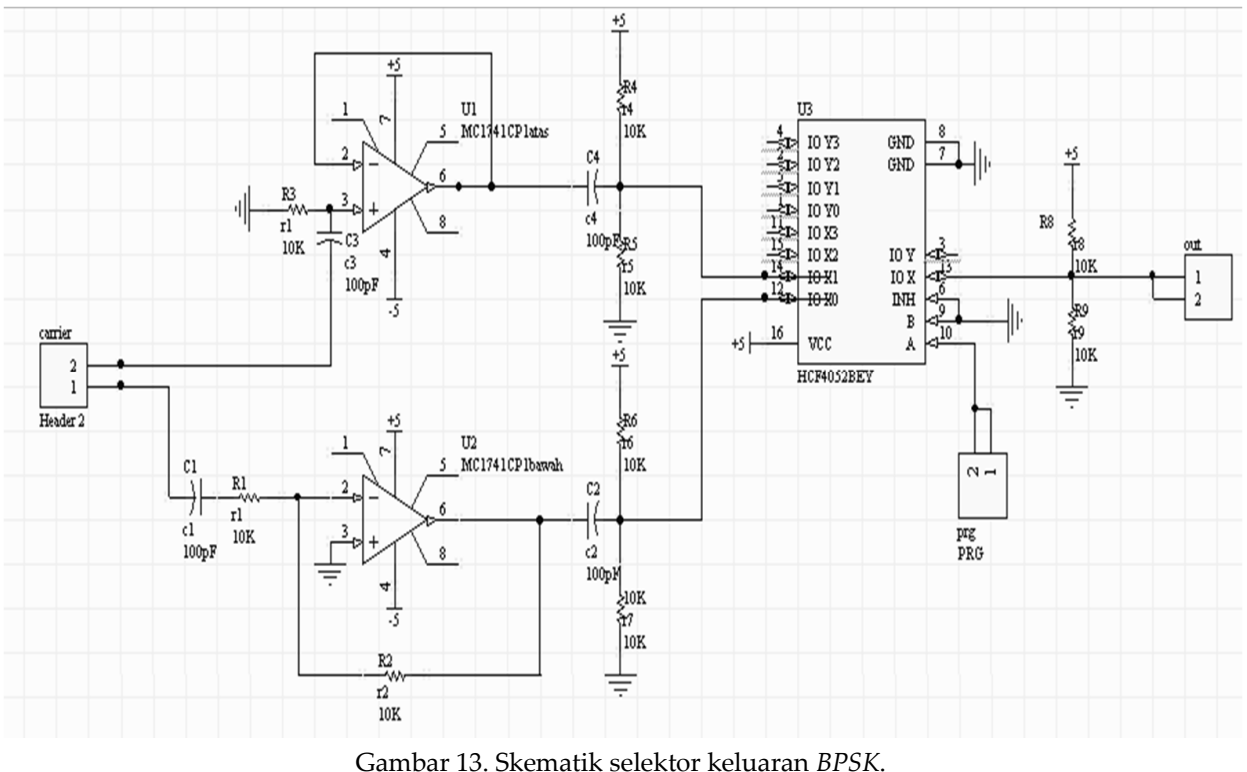

\subsection{Modul Modulator FM}

Keluaran dari bagian modulator BPSK yang disebut sinyal analog bandpass masih memiliki frekuensi yang terlalu rendah jika langsung digunakan untuk transmisi secara nirkabel. Oleh karena itu keluaran dari bagian modulator BPSK perlu ditranslasikan ke frekuensi yang lebih tinggi. Untuk mentranlasikan sinyal analog bandpass ke frekuensi yang lebih tinggi akan digunakan modulator analog. Modulator analog dasar meliputi modulator $A M$ dan FM. Pada tugas akhir ini dipilih modulator FM versi Ronica yang bekerja pada jangkauan frekuensi $88 \mathrm{MHz}-108 \mathrm{MHz}$.

\section{Pengujian dan Pembahasan}

Pengujian dilakukan pada bagian pemancar dan penerima dengan melihat keluaran dari masing-masing blok yang telah dijelaskan pada subbab sebelumnya dan membandingkan dengan teori-teori yang berlaku.

\subsection{Pengujian Simulator Data (Pseudo Random Generator) (Titik A)}

Sumber data digital yang digunakan adalah suatu Pseudo Random Generator (PRG) yang memiliki shift register 5 tingkat sehingga diperoleh simulasi data acak dengan 
periode 31 bit. Adapun sinyal keluaran PRG dapat dilihat pada Gambar 15, dengan bitrate 9600 bps.

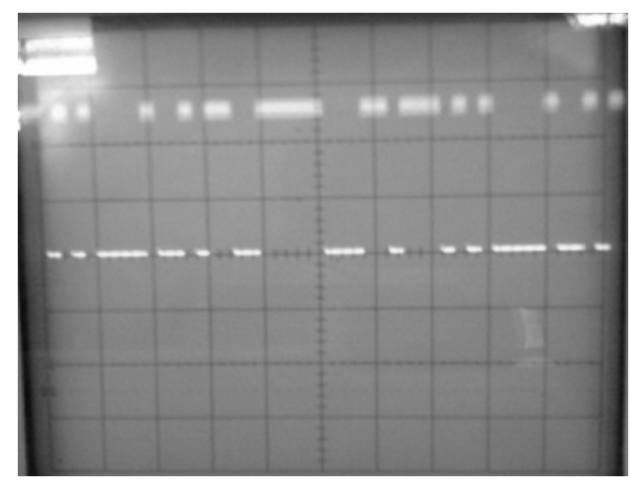

Gambar 15. Sinyal Pseudo Random Generator(PRG).

\subsection{Pengujian Bagian Modulator BPSK}

Seperti telah dijelaskan sebelumnya, bagian modulator BPSK dapat digambarkan pada gambar 16. Label huruf A, B, C, dan seterusnya menunjukkan titik uji yang telah dipilih. Sinyal-sinyal pada titik-titik uji tersebut akan ditampilkan dengan osiloskop dan dibandingkan dengan teori-teori yang berlaku.

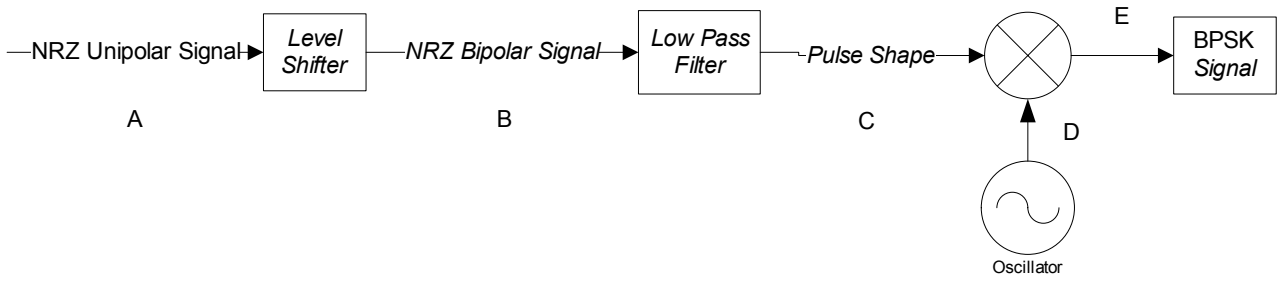

Gambar 16. Gambar titik pengujian di Modulator BPSK.

\subsubsection{Pengujian Level Shifter (Titik B)}

Untuk menggeser tegangan sinyal informasi dari $\mathrm{V}$ dan ground menjadi $+\mathrm{V}$ dan $-\mathrm{V}$ yang berfungsi untuk mendapatkan kondisi perubahan fasa $180^{\circ}$ pada saat terjadi perubahan bit 1 ke 0 atau sebaliknya. Dari gambar terlihat bahwa sinyal masukan dari $P R G$ memiliki level tegangan sebesar $5 \mathrm{Vpp}$ yang dapat diubah menjadi $+2,5 \mathrm{Vp}$ dan $2,5 \mathrm{Vp}$.

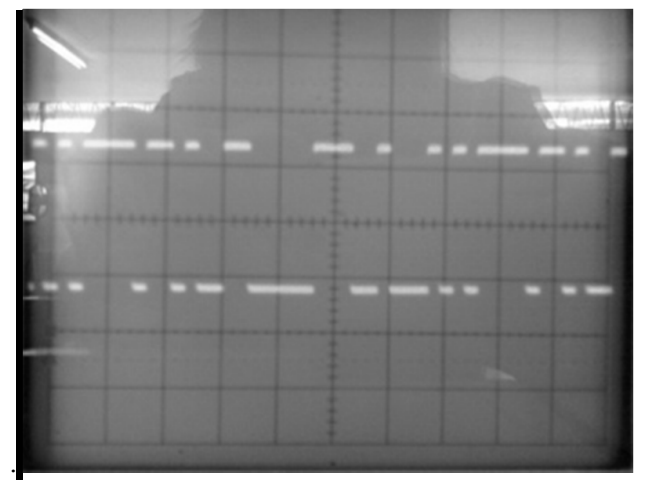

Gambar 17. Sinyal level shifter. 


\subsubsection{Pengujian Tapis Lolos Rendah Bessel orde 6 (Titik C)}

Tapis di sini digunakan untuk mengurangi derau yang masuk ke bagian modulator BPSK. Pada perancangan ini digunakan tapis dengan lebar pita $96 \mathrm{kHz}$. Keluaran dari bagian ini dapat dilihat pada gambar 18. Tapis ini dipilih sedemikian rupa, sehingga sinyal kotak yang ditransmisikan berkurang deraunya tanpa menimbulkan distorsi yang berlebihan pada bentuk sinyal kotaknya.

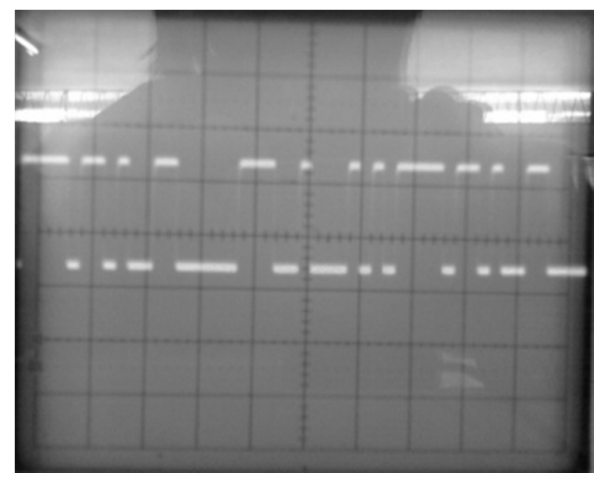

Gambar 18. Sinyal keluaran Tapis Lolos Rendah.

\subsubsection{Pengujian Bagian Osilator (Titik D)}

Bagian osilator digunakan sebagai penghasil sinyal sinusoid sebagai sinyal pembawa. Sesuai dengan spesifikasi besarnya frekuensi sinyal pembawa dapat divariasikan antara $10 \mathrm{kHz}-50 \mathrm{kHz}$ dan besarnya amplitudonya dapat divariasikan juga.

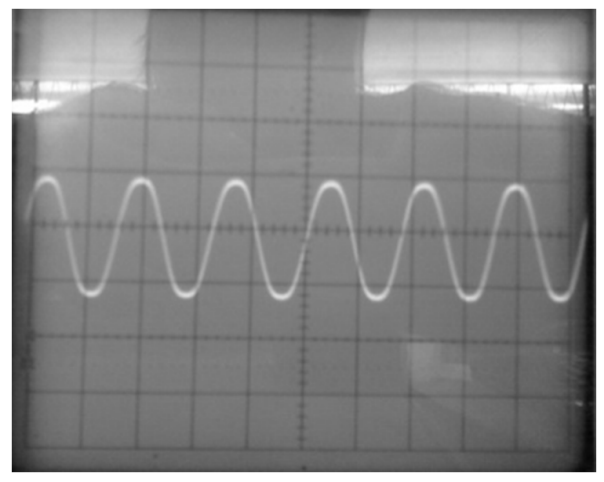

Gambar 19. Sinyal keluaran osilator.

\subsubsection{Pengujian Selektor Keluaran BPSK (Titik E)}

Bagian pencampur digunakan untuk mencampur sinyal keluaran dari tapis pelewat rendah dengan keluaran dari osilator. Hasil perkalian kedua sinyal ini akan menghasilkan sinyal BPSK seperti dapat dilihat pada gambar di bawah ini. Sinyal BPSK adalah sinyal yang menggunakan perubahan fasa 180 derajat sebagai penanda bit 1 dan bit 0 . Dari Gambar 20, terlihat bahwa saat ada transisi bit dari 0 ke 1 atau sebaliknya ada perubahan fasa pada sinyal keluaran pencampur, ditandai dengan bagian yang dilingkari. 


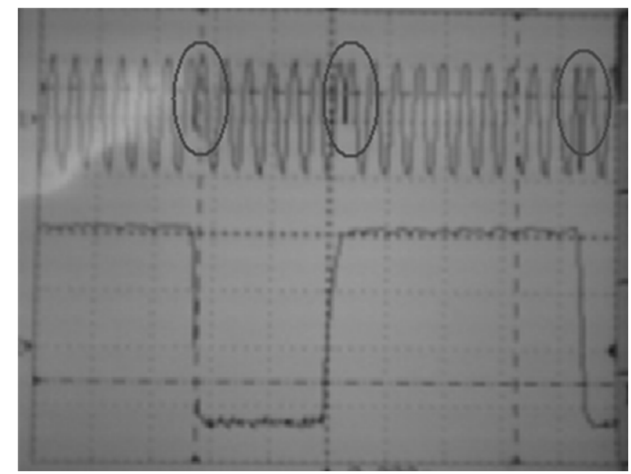

Gambar 20. Sinyal Keluaran BPSK dengan fc $=48 \mathrm{KHz}$

\subsection{Pengujian Pemancar $F M$}

Bagian pemancar $F M$ digunakan untuk mentranlasikan sinyal analog passband ke frekuensi radio agar bisa dipancarkan. Berdasarkan pengujian yang telah dilakukan, pemancar $F M$ yang digunakan memiliki jangkauan frekuensi dari $80 \mathrm{MHz}$ sampai dengan $108 \mathrm{MHz}$. Kemudian akan dicari daerah frekuensi kosong yang tidak dipakai oleh pemancar lain tetapi masih berada di dalam jangkauan pemancar $F M$ yang digunakan. Dari hasil pencarian itu dipilih frekuensi $80 \mathrm{MHz}$ sebagai frekuensi pembawa modulator FM. Gambar 21 menunjukkan spektrum sinyal keluaran osilator pemancar FM yang ditampilkan oleh osiloskop. Dapat dilihat bahwa ada dua puncak yaitu di frekuensi $40 \mathrm{MHz}$ dan $80 \mathrm{MHz}$. Untuk selanjutnya, sinyal dengan frekuensi $40 \mathrm{MHz}$ akan dihilangkan dengan proses pemfilteran dan sinyal dengan frekuensi $80 \mathrm{MHz}$ yang akan diloloskan untuk dipancarkan.

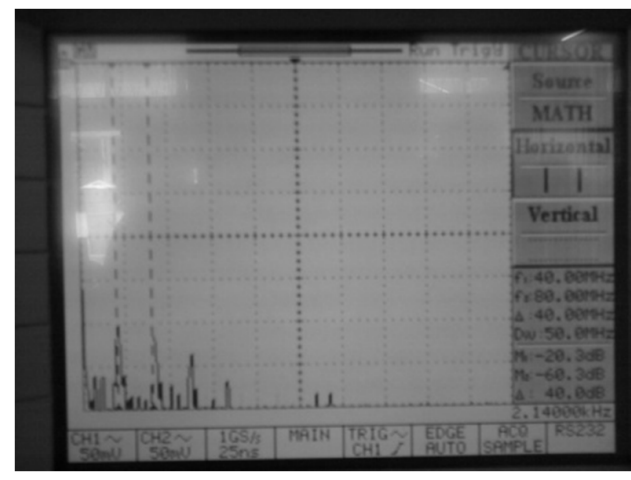

Gambar 21. Sinyal Keluaran Pemancar FM.

\section{Kesimpulan}

Berdasarkan pengujian yang telah dilakukan, secara umum terlihat bahwa sistem perangkat modulator BPSK yang dibangun dapat bekerja dengan baik. Berdasarkan proses perancangan dan pengujian yang telah dilakukan, maka penulis dapat mengambil beberapa kesimpulan.

1. Perancangan pseudorandom generator dengan menanamkan algoritma register geser 5 tingkat dengan mikrokontroler AVR ATTINY13A dapat berfungsi dengan baik dan dapat diatur dengan bitrate bervariasi dari 1200, 2400, 4800 dan 9600 bps. 
Perancangan Sistem Modulator Binary Phase Shift Keying Deddy Susilo, Budihardja Murtianta, Arivia Aurelia Devina Pramono

2. Untai tapis lolos rendah Bessel orde 2 dengan fc $48 \mathrm{kHzdapat}$ berfungsi memperhalus hasil keluaran pseudorandom generator dan level shifter.

3. Untai selektor keluaran BPSK dapat berfungsi dengan baik untuk pemilih sinyal sinus $0^{\circ}$ dan $180^{\circ}$.

4. Pemancar FM dapat menghasilkan sinyal paling tinggi pada frekuensi $80 \mathrm{MHz}$.

\section{Daftar Pustaka}

[1] B. Murtianta, "Sistem Modulator dan Demodulator BPSK dengan Costas Loop," Jurnal Techne, Fakultas Teknik Elektronika dan Komputer Universitas Kristen Satya Wacana, pp. 17-26, Vol. 14 No. 1, April 2015.

[2] B. Murtianta, D. Susilo, A. A. D. Pramono, "Perancangan dan Realisasi Perangkat Keras Demodulator BPSK dengan Costas Loop," Jurnal Techne, Fakultas Teknik Elektronika dan Komputer Universitas Kristen Satya Wacana, pp. 75-88, Vol. 14 No. 2, Oktober 2015.

[3] Setiawan, Yusuf, "Alat Peraga Modulator Demodulator BPSK", Skripsi Fakultas Teknik Jurusan Teknik Elektro, 2005.

[4] Couch, Leon W., "Digital and Analog Communication System", 7rd ed, Pearson Education, Inc., New Delhi, 2007.

[5] Lathi, B. P., "Modern Digital and Analog Communication System", Oxford University Press, Inc., New York, 1998.

[6] Feliciano, David P. dan Rivera, Jose L.C., "Digital Implementation of a Second Order Costas Loop Demodulator", Project Report Electrical Engineering University of Puerto Rico, Mei 2004.

[7] Smith, David R., "Digital Transmision System", 3 $3^{\text {rd }}$ ed, Kluwer Academic Production, Massachussets, 2004.

[8] Mancini, Ron, “Op Amps for Everyone”, Texas Instrument, 2001. 